UDC 621.371: 621.372: 621.315.1.052.63

V. Balashov, Dr.Sc., A. Lashko, Ph.D, L. Lyakhovetskiy, Ph.D, A. Yanevich

SE "Odessa scientific research institute of communication", Bunina str. 23, Odessa, Ukraine, 65026

\title{
Characteristics of broadband access on building electric wiring network
}

The telecommunication technology PLC (Power Line Communication) is researched in given article. The method of calculation of frequency characteristics of telecommunication channel formed on base of building electric wiring network is proposed. The interference in PLC TS (transmission system) and achieved by PLC TS data transmission rate are calculated for typical network fragment under the different conditions. References 8, figures 7, tables 1 .

Keywords: power line communication; transmission system; data transmission rate; building electric wiring network.

\section{Introduction}

In recent years the technologies of data transmission on electric power supply networks, including building electric wiring networks, are developed rapidly. These technologies are called PLC. The most popular applications of PLC technologies are smart grids and broadband access.

For effective adoption PLC technologies on Ukrainian broadband networks it is necessary to develop science-based recommendations regarding designing and maintenance of PLC equipment and networks taking into account specificity of domestic electric wiring networks. For creation of such recommendations there is necessity to develop methods of PLC networks modeling and to evaluate these networks characteristics and data transmission rates achieved on these networks.

\section{Main body}

Building electric wiring network has branched structure in general case. As an example the typical structure of building electric wiring network is given on Fig. 1. This network consists of wire segments (1), connections (2), joints (3), mounting devices (4) and loads (5) - electric energy consumers. The entrance shield (6) is set on building input. Domestic building electric wiring networks are build commonly on ППВ and АППВ types wires.

The building electric wiring network modeling method based on decomposition of branched building electric wiring (BBEW) circuits and creation of scattering matrix [7] is used. According to this method it is necessary to compose equivalent circuit of building electric wiring network as connection of elementary multipoles for building electric wiring circuits transmission parameters calculation.

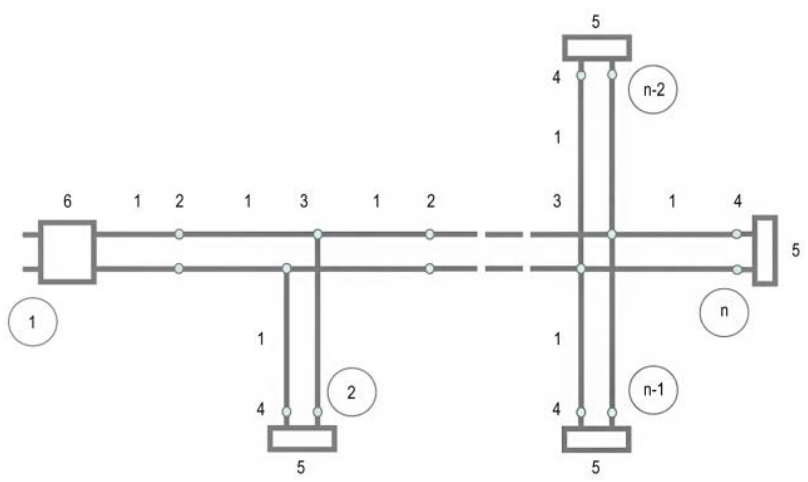

Fig. 1. The typical structure of branched building electric wiring network (The digits in the circles denote the order numbers of input and output poles)

Figure 2 shows the decomposition model of branched building electric wiring network, the structure of which is shown in Fig. 1.

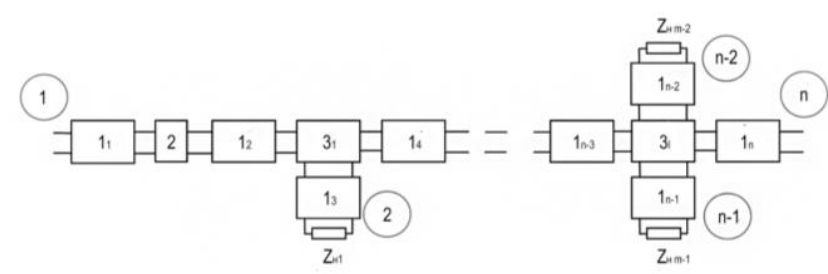

Fig. 2. Decomposition model of branched building electric wiring network: 1 - wire segments, 2 - wire connections, 3 - joints, $Z_{H}$ - load resistance

The best manner of multipole transmission parameters describing is to use scattering matrix.

To calculate elements of scattering matrix $[\mathrm{S}]_{\Sigma}$ of connection of two multipoles with scattering matrix $[S]_{1}$ and $[S]_{2}$ the formulas [7] are used:

$$
\begin{aligned}
& S_{11 \Sigma}=S_{111}+S_{121}\left(E-S_{112} S_{221}\right)^{-1} S_{112} S_{211} \\
& S_{12 \Sigma}=S_{121}\left(E-S_{112} S_{221}\right)^{-1} S_{122} \\
& S_{21 \Sigma}=S_{212}\left(E-S_{221} S_{112}\right)^{-1} S_{211} \\
& S_{22 \Sigma}=S_{222}+S_{212}\left(E-S_{221} S_{112}\right)^{-1} S_{221} S_{122}
\end{aligned}
$$


where $\mathrm{E}-$ the identity matrix. The third index $(1,2)$ in expressions (1) is owned respectively to the scattering matrix of the first and the second multipoles. In a general case $S_{\mathrm{ij} 1}$ and $S_{\mathrm{ij} 2}$ at $1 \leq \mathrm{i}, \mathrm{j} \leq 2$ can be either elements or scattering matrix blocks.

Using of decomposition method and formulas for calculation the elements of scattering matrix of complicated multipoles based on known elements of simple multipoles scattering matrixes $[3,7]$ made it possible to formulate an algorithm for calculation transmission parameters of BBEW, which consists of next steps:

1) composition the BBEW block diagram;

2) carrying out the decomposition of the BBEW in several simplest components;

3) calculation the scattering matrix of each component, that is a part of BBEW [3 - 7];

4) calculation the scattering matrix of first group of two components connected among ourselves in the direction from the input to the output pole using the formulas (1);

5) calculation the scattering matrix of the bloc of first components group (step 4) and connected to it the next component using the formulas (1);

6) continuing creation of groups of connected components and calculation the scattering matrix of them. Finishing of group creating while connecting the last component which have the output pole;

7) calculation transmission parameters of BBEW between different poles based on the values of the BBEW scattering matrix elements, that is defined in points $1-6$.

Note. Attenuation $a_{i j}$ and phase $\varphi_{i j}$ between different input (i) and output (j) of BBEW poles is determined by known formulas $[3,7]$ :

$$
a_{i j}=20 \lg \left[\frac{1}{S_{i j}}\right], \phi_{i j}=-\arg S_{i j} .
$$

The knowledge of building electric wiring circuit scattering matrix makes it possible to define transfer function in all possible signal propagation directions and return losses on the input and output poles of the building electric wiring network $[3,7]$.

As an example the building electric wiring network fragment shown on Fig. 3 is considered. This fragment consists of segments of ППВ $2 \times 4$ type wire (length $10 \mathrm{~m}$ ) and $\Pi \Pi B$ 2x2,5 type wire (lengths 2,5 $\mathrm{m}$ and 7,5 m).

The calculated frequency characteristics of attenuation $\alpha$ between the considered fragment poles $1-8$ in frequency range $1-32 \mathrm{MHz}$ for different loads (wave impedance $\left(Z_{\mathrm{w}}\right)$, short circuit (SC), open-circuit $(O C))$ on poles are given on Fig. 4 .

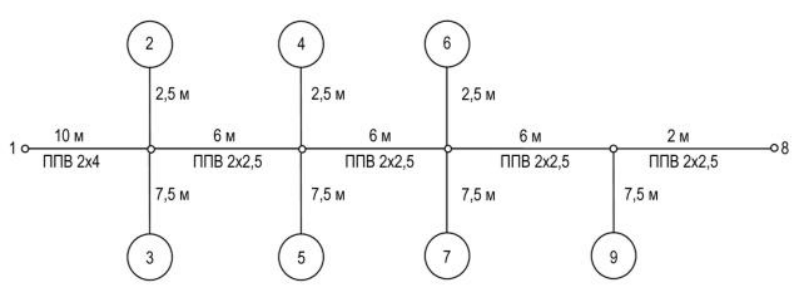

Fig. 3. Fragment of building electric wiring network

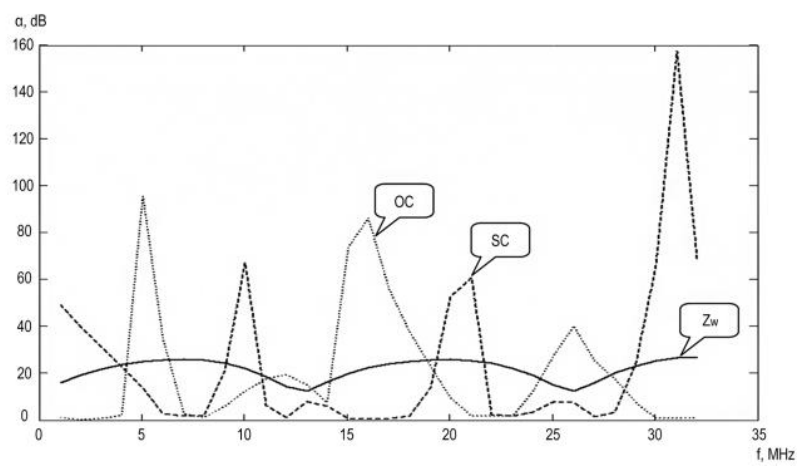

Fig. 4. Frequency characteristics of attenuation between the considered fragment poles $1-8$ in frequency range $1-32 \mathrm{MHz}$ for different loads on poles

Using the method published in [1], the interference in PLC TS when working on the considered building electric wiring network fragment was calculated for such given data:

- frequency plan $25 \mathrm{MHz}-\mathrm{PB}$ [2];

- number of used subcarriers $n=235$;

- number of first used subcarrier $m=21$;

- number of samples in an orthogonality interval $\mathrm{N}=512$;

- number of samples in a guard interval $L=32$;

- power spectral density (PSD) of transmitted signal according to [8];

- loads on all poles of the given fragment are $Z_{w}$, SC or OC.

The results of the calculations of dependence of the ratio $h$ of the effective values of the interference and the signal at the input of the receiver on subcarrier number I and number of sample $\mathrm{k}_{\mathrm{T}}$, from which the signal processing begins in the receiver, for the case of $\mathrm{OC}$ load on all poles of the given network fragment are shown on Fig. 5. The corresponding parameter $h$ dependence on subcarrier number $\mathrm{I}$ at the optimum $\mathrm{k}_{\mathrm{T}}$ (on the criterion of minimum of arithmetical mean of value $\mathrm{h}$ across all subcarriers) is shown on Fig. 6 . .

Using method published in [2] the maximum achieved number of bits that can be delivered over 
a OFDM (Orthogonal Frequency Division Multiplexing) symbol period on each subcarrier of the PLC TS and maximum achieved PLC TS data rate when

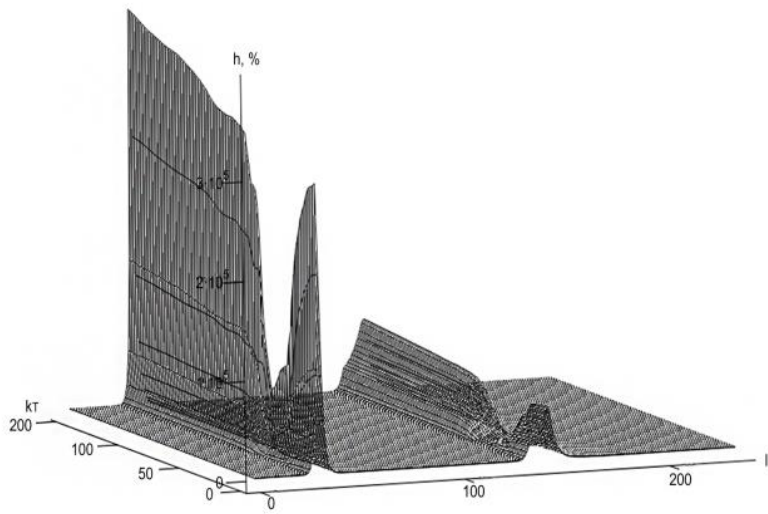

Fig. 5. The parameter $h$ dependence on $I$ and $k T$ for the considered network fragment (all loads are OC)

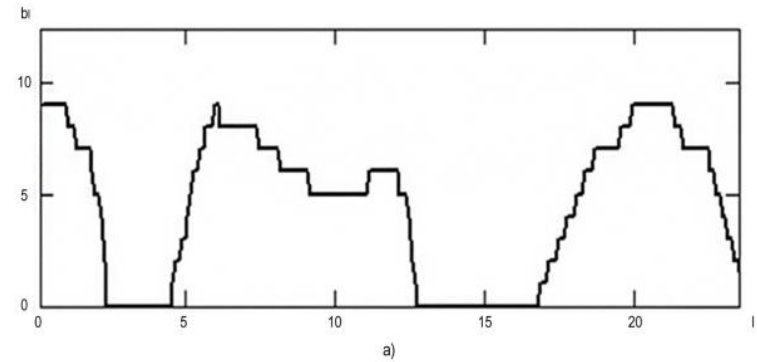

working on the given network fragment are defined taking into account calculated interference (Fig. 7, Table 1).

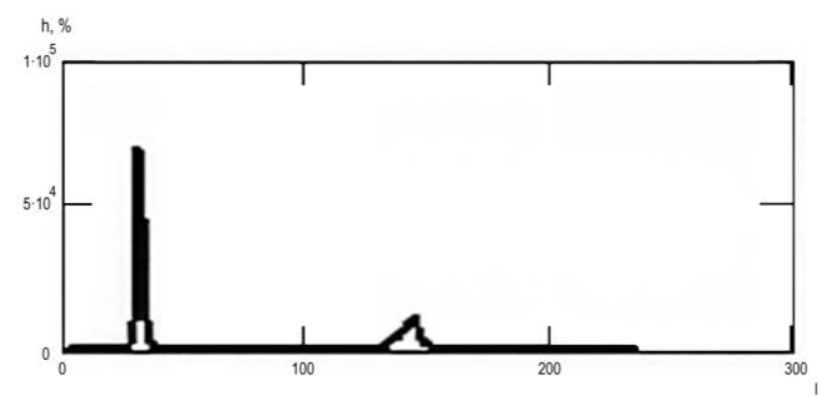

Fig. 6. The parameter $h$ dependence on $I$ at the optimum $k_{T}$ for the considered network fragment (all loads are OC)

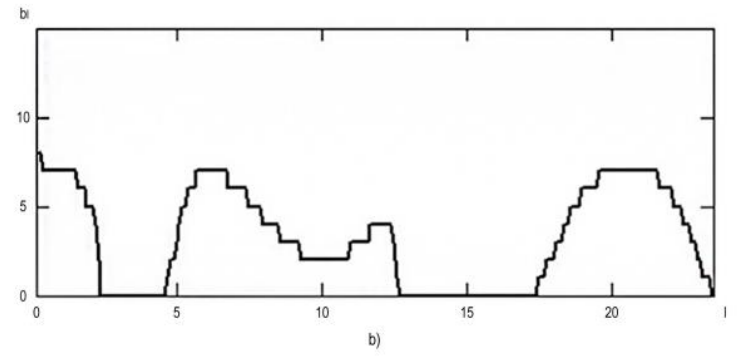

Fig. 7. Dependence of the maximum achieved number of bits, that can be delivered over a OFDM symbol period on subcarrier of the PLC TS, on subcarrier number at power spectral density of noise: a) minus 140 $\mathrm{dBm} / \mathrm{Hz}$; b) minus $100 \mathrm{dBm} / \mathrm{Hz}$

Table 1. The maximum achieved PLC TS data rate, Mbit/s, when working on the given network fragment (frequency plan $25 \mathrm{MHz}-\mathrm{PB}$ )

\begin{tabular}{|c|c|c|c|}
\hline \multirow{2}{*}{ Load } & \multicolumn{3}{|c|}{ Power spectral density } \\
\cline { 2 - 4 } & $-140 \mathrm{dBm} / \mathrm{Hz}$ & $-120 \mathrm{dBm} / \mathrm{Hz}$ & $-100 \mathrm{dBm} / \mathrm{Hz}$ \\
\hline $\mathrm{Zw}$ & 155,469 & 120 & 25,938 \\
\hline SC & 105,156 & 104,297 & 76,797 \\
\hline OC & 82,578 & 82,188 & 59,219 \\
\hline
\end{tabular}

\section{Conclusion}

The developed method allows calculating achieved PLC TS data transmission rate on building electric wiring network of arbitrary topology. The analysis of calculations results demonstrates that data transmission rate on building electric wiring network depends on building electric wiring network topology and loads on the network poles significantly

\section{References}

1. Balashov, V. O., Lyakhovetskiy, L. M., Zablotskiy, S. A., Karpenko, K. M. (2013). Doslidzhennya interferentsiynih zavad u sistemah shirokosmugovogo dostupu BPL po merezhi elektroprovodki. Naukovi pratsi ONAC after O.S. Popov No. 2. Pp. $41-46$.

2. Balashov, V. A., Vorobienko, P. P., Lyakhovetskiy, L. M. (2012). Sistemi peredachi ortogonalnyimi garmonicheskimi signalami. Moskow: Eko-trendz, Pp. 228.

3. Feldshteyn, A. L., Yavich, L. R. (1971). Sintez chetyirehpolyusnikov i vosmipolyusnikov na SVCh. Moskow: Svyaz, P. 388.

4. Lashko, A. G., Lyakhovetskiy, L. M., Zablotskiy, S. A. (2013). Opredelenie parametrov 
peredachi razvetvlennoy domovoy elektroprovodki. Zv'yazok, No. 2. Pp. $33-36$.

5. Lashko, A. G., Lyakhovetskiy, L. M., Zablotskiy, S. A. (2013). Vyisokochastotnyie parametryi peredachi dvuhzhilnyih provodov domovoy elektroprovodki, primenyaemyih $v$ tehnologii BPL. Zv'yazok, No. 1. Pp. $27-31$.

6. Lashko, A. G. (2011). Matritsa rasseyaniya tochki otvetvleniya vnutridomovoy elektroprovodki. Naukovi pratsi ONAC after O.S. Popov, No. 1, Pp. 123-126
7. Sazonov, D. M., Gridin, A. N., Mishustin, B. A. (1981). Ustroystva SVCh. Moskow: Vyisshaya shkola, P. 295.

8. (2011). ITU-T Recommendation G.9964 Unified high-speed wireline-based home networking transceivers - Power spectral density specification [Electronic resource] / International Telecommunication Union. Dec. 2011. Access mode: https://www.itu.int/rec/dologin pub.asp? lang=s\&id=T-REC-G.9964-201112-I!!PDFE\&type=items. - Title screen. - Date of access: 22.09.2015.

Поступила в редакцию 24 декабря 2015 г.

УДК 621.371: 621.372: 621.315.1.052.63

В.О. Балашов, д. - р. техн. наук, А.Г. Лашко, канд. техн. наук, Л.М. Ляховецький, канд. техн. наук, О.К. Яневич

ДП «Одеський науково-дослідний інститут зв'язку», вул. Буніна, 23, м. Одеса, 65026, Україна.

\section{Характеристики широкосмугового доступу по мережі будинкової електропроводки}

B статті досліджується телекомунікаційна технологія PLC (Power Line Communication). Запропонована методика розрахунку частотних характеристик телекомунікаційного каналу, сформованого на базі мережу будинкової електропроводки. Розраховані інтерфреренційні завади у СП (система передавання) PLC і швидкість передавання даних, що може бути досягнута за різних умов. Бібл. 8, рис. 7, табл. 1.

Ключові слова: система передавання; швидкість передавання даних; будинкова мережа електрозв'язку.

УДК 621.371: 621.372: 621.315.1.052.63

В.А. Балашов, д.- р. техн. наук, А.Г. Лашко, канд. техн. наук., Л.М. Ляховецкий, канд. техн. наук,

\section{А.К. Яневич}

ГП «Одесский научно-исследовательский институт связи», ул. Бунина, 23, г. Одесса, 65026, Украина.

\section{Характеристики широкополосного доступа по сети домовой элек- тропроводки}

B статье исследуется телекоммуникационная технология PLC (Power Line Communication). Предложена методика расчета частотных характеристик канала связи, сформированного на базе сети домовой электропроводки. Рассчитаны интерференционные помехи в СП (система передачи) PLC и скорость передачи данных, которая может быть достигнута при различных условиях. Библ. 8, рис. 7, табл. 1.

Ключевые слова: система передачи; скорость передачи данных; домовая сеть электропроводки.

\section{Список использованных источников}

1. Balashov V.O., Lyakhovetskiy L.M., Zablotskiy S.A., Karpenko K.M. "Doslidzhennya interferentsiynih zavad u sistemah shirokosmugovogo dostupu BPL po merezhi elektroprovodki". - Naukovi pratsi ONAC after O.S. Popov - 2013. - no. 2. - pp. $41-46$. 
2. Balashov V.A., Vorobienko P.P., Lyakhovetskiy L.M. "Sistemi peredachi ortogonalnyimi garmonicheskimi signalami”. - Moskow: - Eko-trendz, 2012. - pp. 228.

3. A.L. Feldshteyn, L.R. Yavich. "Sintez chetyirehpolyusnikov i vosmipolyusnikov na SVCh". - Moskow: Svyaz, 1971. - p. 388.

4. Lashko A.G., Lyakhovetskiy L.M., Zablotskiy S.A. "Opredelenie parametrov peredachi razvetvlennoy domovoy elektroprovodki”. - Zv'yazok, - 2013. - no. 2. pp. 33 - 36.

5. Lashko A.G., Lyakhovetskiy L.M., Zablotskiy S.A. "Vyisokochastotnyie parametryi peredachi dvuhzhilnyih provodov domovoy elektroprovodki, primenyaemyih v tehnologii BPL”. - Zv'yazok, - 2013. - no. $1-$ pp. $27-31$.

6. Lashko A.G. "Matritsa rasseyaniya tochki otvetvleniya vnutridomovoy elektroprovodki". - Naukovi pratsi ONAC after O.S. Popov, no. 1, 2011. - pp. 123-126.

7. D.M. Sazonov, A.N. Gridin, B.A. Mishustin. "Ustroystva SVCh". - Moskow: Vyisshaya shkola, 1981. p. 295.

8. ITU-T Recommendation G.9964 Unified high-speed wireline-based home networking transceivers Power spectral density specification [Electronic resource] / International Telecommunication Union. Dec. 2011. - Access mode: https://www.itu.int/rec/dologin_pub.asp?lang=s\&id=T-REC-G.9964201112-I!!PDF-E\&type=items. - Title screen. - Date of access: 22.09.2015. 